\title{
Changing How We Teach Acid-Base Chemistry
}

\section{A Proposal Grounded in Studies of the History and Nature of Science Education}

\author{
Maria Rut Jiménez-Liso ${ }^{1}$ (D) - Luisa López-Banet ${ }^{2}$ (D) $\cdot$ Justin Dillon $^{3}$ (D)
}

Published online: 15 August 2020

(C) Springer Nature B.V. 2020

\begin{abstract}
We propose explicit and implicit approaches for the teaching of acid-base chemistry based on research into the history and nature of science (NoS). To support these instructional proposals, we identify four rationales for students to understand acid-base processes: daily life, socio-scientific, curriculum, and history of science. The extensive bibliography on misconceptions at all educational levels justifies the need for a change from the usual pedagogical approaches to teaching the acid-base domain (traditionally involving conceptual-focused teaching) to a deeper and more meaningful approach that provides (implicitly or explicitly) a chance to reflect on how scientific knowledge is constructed. Controversial moments in science from 1923, when three researchers (Bronsted, Lowry, and Lewis) independently enunciated two theories from two different paradigms (dissociation and valence electron), underpin our first sequence with an explicit NoS approach for both lower secondary school and upper secondary or university levels. Our inquiry teaching cycle promotes the transformation of a hands-on activity (using cabbage as an indicator) into an inquiry, and subsequently, we use an historical model to propose a sequence of activities based on the modeling cycle of Couso and Garrido-Espeja for lower secondary school. Finally, we identify some implications for a model-focused teaching approach for upper secondary and university levels using more sophisticated models.
\end{abstract}

\section{Introduction}

Researchers in the area of the nature of science (NoS) often provide recommendations for teachers. It is usually suggested, directly or indirectly, that teachers should improve their

Maria Rut Jiménez-Liso

mrjimene@ual.es

1 Sensociencia Team, CEIMAR-University of Almeria, Almeria, Spain

2 Department of Science Education, University of Murcia, Murcia, Spain

3 CRISTEME, University of Exeter, Exeter, UK 
knowledge about what science is and how it is constructed, so that they can transfer this knowledge to the classroom, transforming it into sequences of activities for their students. For example, Nouri et al. (2019) recommend a well-designed history of science (HoS) intervention to convey essential lessons about the NoS consensus described by McComas (2006) such as science depends on empirical evidence; cultural, political, and social factors influence science; or science has a tentative or fallible nature.

Many authors identify multiple potential benefits for learning NoS through such approaches: teaching scientific methods, challenging myths related to how science works, and differentiating between idealized scientific laws and observations (Niaz 2009). However, they also highlight that research involving rationales and strategies for teaching HOS is scarce and Nouri et al. (2019) recommend expanding science teacher educators' rationales for teaching HOS to inspire a broader array of orientations and teaching strategies. They also suggest paying special attention to instructors' orientation towards teaching HOS which may have an impact on their effectiveness.

Such recommendations usually arise from studies focusing on the benefits of NoS for students and research on what teachers think, their beliefs about NoS, or in a less declarative way and close to their educational reality, the connection (or otherwise) between this knowledge and what the teacher really does in their classes (Leden et al. 2015). One of those recommendations involves the design of NoS classroom activities: explicitly and implicitly (Duschl and Grandy 2013) and using reflective approaches to NoS teaching and learning. These approaches open up the range of possibilities for teachers. For example, proposing explicit general activities, linked (or not) to a specific issue of science content, to develop students' understanding of an aspect of the NoS consensus view (Lederman 2007; McComas 2006). Such an activity might involve the use of a mystery box to help students to learn about observation, interpretation, and argumentation (Cavallo 2007; Rau 2009). Another example involves scientific practices, such as the National Research Council's (2000) inquiry into the problem of the tsunami on the US West Coast or "Mrs Graham's" class which tackled the problem of leafless trees with explicit reflection such as metamodeling learning progression (Schwarz et al. 2009) on how science is built. In this paper, we use Garrido-Espeja and Couso's (2017) definition of a model which is a "small number of big or core ideas (Harlen 2010) that have the potential to explain a lot of different phenomena (Izquierdo-Aymerich and Aduriz-Bravo 2003), such as the particle model of matter" or, indeed, the chemical change model.

Implicit and explicit NoS teaching approaches (Duschl and Grandy 2013) have a place in the high school science curriculum (12-18 years old) because an initial study of what science is is often included. At the same time, in chemistry courses, some topics such as atomic structure, the periodic table, or acid-base are often introduced through their historical developments. This history of chemistry topics present in curricula allows the design of authentic scientific practices (implicit approach Burgin and Sadler 2016).

The content overload in the Spanish science curriculum forces some teachers to dispense with developing the initial lesson about what science is and how it is built or with spending more time in deepening these NoS aspects when working on some historical development present in the curriculum, i.e. atomic structure, periodic table, etc. Thus, before deciding the approach on explicit or implicit teaching, the first teacher decision is to develop or omit this initial NoS lesson and the second is to decide whether to deepen or not the historical developments present in the curricula. 
We turn now to address the issue faced by teachers: how to translate these NoS teaching approaches to sequences of activities on a specific topic? In this theoretical article examining teaching practice, we want to focus on the historical development of acid-base theories (Arrhenius, Bronsted-Lowry and Lewis) to analyse the steps to follow to design sequences of activities for different NoS approaches.

\section{Objectives and Purposes}

The main objective of this paper is to translate the explicit and implicit NoS approaches using the historical development of acid-base domain into activity sequences that can be used as a reference by teachers. In the next section we will outline the importance of teaching the topic of acids and bases because we understand that the first decision for a teacher is whether to spend time on the historical development of the acid-base domain present in chemistry curricula at secondary level, high schools and university level (in analytical and inorganic chemistry subjects).

Finally, we discuss how to design sequences of activities. We examine conventional teaching approaches to the topic and its consequences in terms of students' alternative conceptions and their difficulties to transfer and apply knowledge and to recognize acid-base models' limits of applicability. In this section, we will use research results (our own and others) from assessments of high school students, university students, both undergraduates and postgraduates, and pre-service teachers to show the common acid-base teaching (concept-focused teaching) approach and its consequences.

These discussions and an acid-base historical development (timeline in Section 4) will help us to analyse the current situation in order to scaffold the design of sequences of activities utilizing different NoS approaches:

1. We will propose NoS sequences with an explicit approach through controversial moments of the acid-base historical development for both lower secondary school and upper or university levels;

2. We will transform a hands-on activity (using cabbage as an indicator) into an inquiry for lower secondary level (Section 7.1) and from it;

3. We will propose a modeling sequence based on the modeling cycle of Couso (2020) and Couso and Garrido-Espeja (2017) using an historical model (Erduran 2001) for the same level (lower secondary school);

4. We will identify some implications about a model-focused teaching for upper secondary and university levels using more sophisticated models.

Finally, we will discuss the change in teachers' awareness of a model-focused teaching approach that extends and gives meaning to the usual concept-focused teaching. In short, in this paper, we are constructing a science teaching learning progression in a theoretical manner (Schneider and Plasman 2011) to build models using the history of acids and bases as a theme which could be used as a reference by teachers in their professional practice.

\section{Why Teach the Topic of Acid-Base?}

Acid-base chemistry is a traditional topic in high schools and universities. Key concepts are presented in analytical and inorganic chemistry subjects in virtually all Spanish and British 
universities. Acid-base processes also appear in other subjects such as ionic equilibria and chemistry lab work. In these subjects, they are often referred to as "acid-base reactions", "acidbase titrations", "ionic solutions", and "acid-base theories".

We have identified four categories of rationales why students need to understand acid-base processes: daily life; socio-scientific; curriculum; and HoS argument. We now discuss each in turn, briefly.

Acids and bases are commonly recognized by students and the general public. People know about acidic sweets, stomach acidity, antacids, etc. (Cros et al. 1986, 1988). Words such as "acid" and "neutral" are used in some TV advertisements ("Fairy is neutral and protects your hands"; "Johnson's pH 5.5 has natural pH"). Nevertheless, understanding of acid-base concepts is still limited. Furthermore, the use of scientific concepts is increasing and highlighted in advertisements to show products both as beneficial or a matter of trust despite misunderstanding of scientific concepts (Jiménez-Liso et al. 2000). Thus, some acid-base contents are necessary to understand the phenomena encountered in daily life.

Pseudoscientists take advantage of the lack of awareness of the population about scientific expressions using it to promote "scientific credibility" to their unfounded proposals of health and home remedies. Poor science is common in advertisements about cosmetics and cleaning "with $\mathrm{pH}$ " products, all sorts of diets and foods that reduce acidity in your body to prevent or treat cancer, etc. Those adverts can serve us as a context to raise socio-scientific controversies (Evagorou and Osborne 2013; Sadler and Zeidler 2009) about medicalization (Domènech Calvet et al. 2015) or alternative treatments (Uskola Ibarluzea 2016).

Although acids and bases are encountered in students' daily life (and social networks), they are rarely taught well at primary school level. For example, in the Spanish primary school curriculum, chemical reactions are only exemplified through oxidations, combustions, and fermentations, with no mention of acid-base reactions. However, if combustion and oxidation are the most used examples of chemical changes, they lead to the establishment of some alternative conceptions such as "all chemical changes are irreversible" (Stavridou and Solomonidou 1998) or "mass is not conserved in chemical reactions" (Stavy 1990). Not surprisingly, some alternative ideas held by students closely match ideas held by people studying science many centuries ago (Wandersee 1986).

The curriculum rationale could be reinforced by the history of science rationale: the knowledge of historical models (Justi and Gilbert 1999a) and the context in which they were formulated could improve understanding of acid-base models, their limitations, and, as a consequence, the conditions required to select each model (Erduran 2001).

Taken together, these arguments justify why teachers need to develop acid-base content in their chemistry curriculum. In the next section, we justify why current acid-base teaching might be changed in order to improve understanding of scientific content.

\section{Acid-Base Historical Development}

Historical aspects of acid-base domain could constitute an educational resource of great relevance to prevent students seeing science as a finished product and to appreciate how some theories and explanations are provisional. For instance, the acid-base historical development would allow teachers to discuss with their students the limitations of each of the acid-base theories and why they were used in the past or still are used (Alvarado et al. 2015). 
In this paper, we use three famous acid-base theories (Arrhenius, Bronsted-Lowry and Lewis), although the historical development of the acid-base domain is as long as the history of chemistry itself. Figure 1 represents a timeline of the acid-base domain showing links with the chemical change models presented by Justi and Gilbert (1999b) and also with some acid-base models reviews (de Vos and Pilot 2001) or history of science books (Taton 1957, 1959; Taton and Goupil 1961).

The historical development of a domain is usually introduced to students in a very condensed manner in order to focus on the last, the most useful or the longest surviving acid-base theories. In this first part of the paper, we only use acid-base "theories" as it is commonly called, but from Section 6, we will be called acid-base "model" to focus on the explanatory and predictive power of the models. This timeline could be a good illustration of the historical development of ideas which is broader than that usually presented to the students. On the left side of the timeline, we use the term pre-model (Justi and Gilbert 1999a) to indicate that an acid-base classification does not have to be explanatory.

In order to understand scientific models, we need to appreciate that they have been constructed to explain and predict phenomena, so the models are more than a descriptive account of the material world. In this sense, acid-base historical models are a good opportunity to understand how change has taken place in the scientific models over time.

Many of the situations where people encounter science involve the use of scientific knowledge, alongside other forms of knowledge, to reach decisions about action. This is often the case for lay people, who typically find science through media portrayals of socio-scientific issues, or through consultations with experts such as medical practitioners. Lay views of science tend to portray such issues as being easily resolved through simple empirical processes (e.g. Driver et al. 1996). This position, however, is often not sustainable, as illustrated by the following examples.

An example of science in the media is the case of enhanced global warming as a result of increased levels of carbon dioxide in the atmosphere due to the combustion of fossil fuels. It is not difficult to find widely different predictions in the media about the likely environmental impact of the burning of fossil fuels. These differences in predictions are based upon the application of models of the atmosphere. Resolving those differences involves a complex interplay between models, empirical evidence and methodological expertise. Understanding

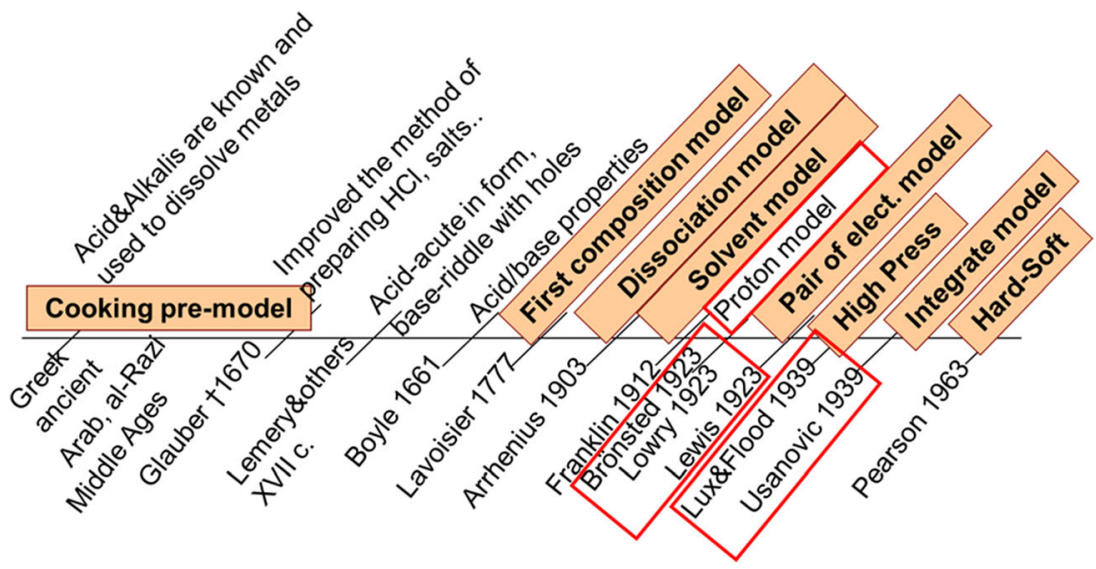

Fig. 1 Acid-base timeline 
how such differences arise, and why they cannot be resolved quickly and simply, involves understanding something about the use of models.

It is not only lay people who encounter science in situations that are characterized by uncertainty. Many experts will be faced with situations where scientific knowledge has to be drawn upon, alongside other considerations, to inform decisions about action in novel situations. A sad and recent example is the current scientific/political/cultural environment with COVID-19. The academic literature now includes several accounts of how experts have to create new knowledge in order to answer questions that emerge in specific situations. Another, much older example, is Brian Wynne's account of how experts had to develop new knowledge about the impact of pollution following the Chernobyl accident impacting upon the milk produced by sheep which grazed on the Cumbrian fells (Wynne 1989). In order to appreciate why the available scientific knowledge may be inadequate to inform action in specific, local conditions, such experts need to understand something about the nature of models in science. So, to summarize, it is necessary to teach models at university level to make the following points:

- In order to have a sophisticated understanding of the conceptual content presented to them in chemistry degree programmes, students need to have some understanding of how the models are built.

- In addition, if the students develop this understanding of the nature of models, it may enable them better to understand situations involving uncertainty, whether as educated citizens, or if they go on to become professional scientists, in their professional practice.

These general arguments about teaching models can be exemplified in the case of acid/base models.

\section{Conventional Acid-Base Teaching}

Conventional chemistry teaching might begin with questions such as "What is an acid?" or "What is a base?"; "What happens when an acid is added to a base, and vice versa?"; "What does $\mathrm{pH}$ mean?"; "Is it always possible to reach $\mathrm{pH}=7$ when an acid is added to a base?" Conventional teaching shows some concepts from Arrhenius and Bronsted-Lowry's theories that we summarized in Fig. 2.

It is possible to recognize some differences between both theories in relation to considering acids and bases as substances (Arrhenius) or as the conjugated acid-base pairs (BronstedLowry). As is normally mentioned, Arrhenius', Bronsted-Lowry's, and Lewis' theories are usually presented together (Tarhan and Acar Sesen 2012). Acid-base theories are introduced in the style of a short story without any connection with the phenomena they want to explain or with the historical problems that inspired them.

By teaching these acid-base theories together we expose the combination of the acid-base concepts (acid, base, neutralization, etc.) of the three theories without appreciating a significant advance between them, which for many students could mean only a terminological change. Teachers (and textbooks) usually say that "Bronsted-Lowry extend the definition of acids and bases” (Nyachwaya 2016, p.510) given by Arrhenius. In this sense, Arrhenius', BronstedLowry's and Lewis' models are often presented several times in chemistry programmes, introducing some inconsistencies in their presentation that lead to "hybrid models" (Justi 


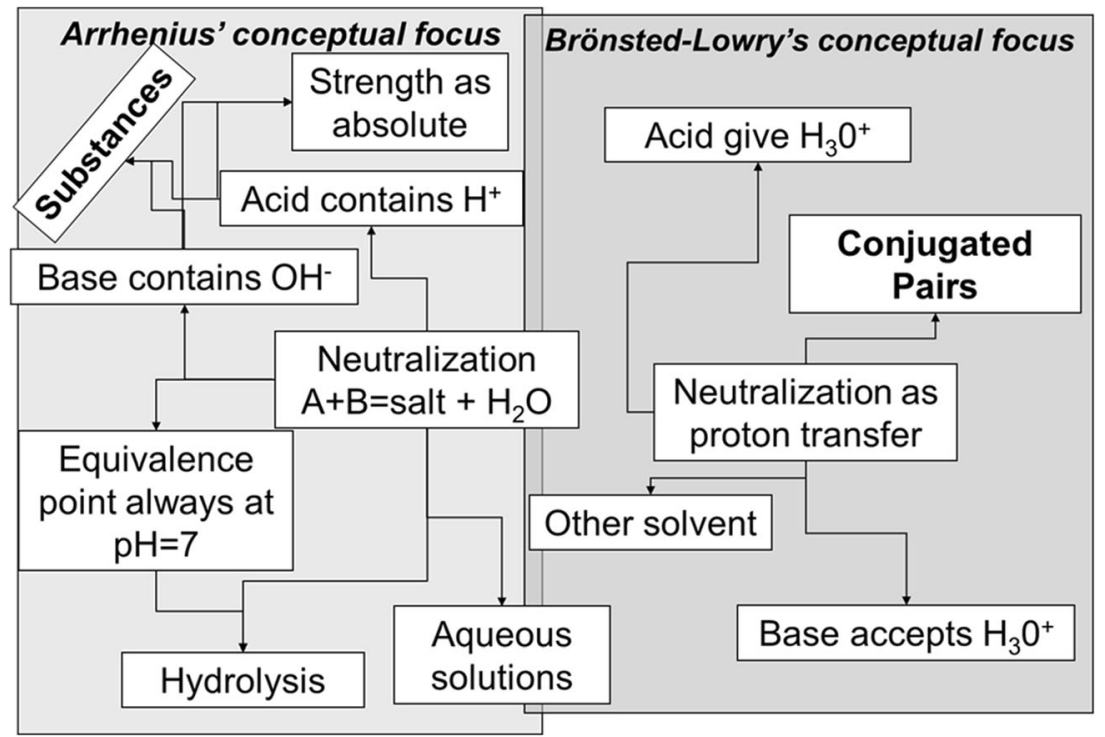

Fig. 2 Arrhenius and Bronsted-Lowry's conceptual focus

and Gilbert 1999a) and some concepts and their definitions are mixed in two or more models (Gericke and Hagberg 2010).

The science education literature is replete with examples of the consequences for students' learning of this typical way of teaching acid-base content focused on the definition of its concepts and with two or three theories introduced simultaneously. In the next sections we will use a review of research results (our own and others) on the understandings of high school students, university students (both undergraduates and postgraduates), and pre-service teachers in order to design some proposals focusing on two approaches, one NoS explicit and the other NoS implicit (Sections 6 and 7 respectively).

\subsection{Consequence I: Students' Alternative Conceptions}

There have been a number of studies into students' misunderstandings of acid-base phenomena (for example McClary and Bretz 2012; Nyachwaya 2016). Many students have difficulties in learning acid-base concepts and the presence of alternative conceptions (Hoe and Subramaniam 2016) can interfere with their understanding. For instance, students think that acids alone are associated with corrosiveness (Demircioğlu et al. 2005; Hoe and Subramaniam 2016; Özmen et al. 2009) and are more dangerous and reactive than bases (Hoe and Subramaniam 2016; Nakhleh and Krajcik 1994; Sheppard 2006). They also think that rain water in an unpolluted area is neutral or the solution formed after adding an acid and a base is always neutral (Banerjee 1991; Hoe and Subramaniam 2016; Scerri 2019; Schmidt 1991). As Quílez (2019) points out, many of these misunderstandings come from students' terminological difficulties. Therefore, students do not understand why the degree of acidity or basicity of two acidic or basic solutions is different, although they have the same concentration (Alvarado et al. 2015). Moreover, a superficial correlation of chemical structures with acidity or basicity may explain why students believed that compounds containing $\mathrm{H}$ will produce $\mathrm{H}^{+}$and 
compounds containing $\mathrm{OH}$ will produce $\mathrm{OH}^{-}$(Demircioğlu et al. 2005; Hoe and Subramaniam 2016).

Besides, the belief that a stronger acid is either the one that produces a higher hydrogen ion concentration, or that has more $\mathrm{H}$ in the formula, or an acid with a higher initial concentration (Demircioğlu et al. 2005; Hoe and Subramaniam 2016; Özmen et al. 2009; Ross and Munby 1991), reveals that students do not apply correctly the definitions of strong and weak to acids and bases (Garnett et al. 1995; McClary and Bretz 2012) and both equilibrium and incomplete dissociation of acid and bases are not considered. Similar problems are found with students' understanding of bases (Hoe and Subramaniam 2016).

Another issue is that students do not totally differentiate between the terms acidity and $\mathrm{pH}$ (Alvarado et al. 2015); they do not consider $\mathrm{pH}$ is providing information about both the $\mathrm{H}^{+}$and $\mathrm{OH}^{-}$concentrations (Garnett et al. 1995), and show either a lack of consideration about the influence of variables such as the temperature or the solvent, using strength and concentration as if they were synonymous or having problems when they must differentiate between an acidbase reaction and a neutralization reaction (Alvarado et al. 2015).

Many of those alternative conceptions are consistent with students using the theory in other contexts to which Arrhenius proposed it. In the next subsection, we are going to look deeper into the difficulties linked to transferring knowledge to new situations or to recognizing the limits of each of the acid-base theories.

\subsection{Consequence II: Difficulties in Transferring and Applying Knowledge}

Based on our own results in the Spanish context (Author 2000), the consequences of acid-base conceptual teaching for both undergraduate and postgraduate chemistry degree students become evident due to (a) students' difficulties to transfer knowledge and (b) the problems recognizing the limits of applicability of acid-base theories:

(a) Transference of knowledge to new situations. Despite having been taught about acid-base concepts many times, undergraduate university students $(n=450)$ from three Spanish universities showed weaknesses in their abilities to recognize an acid-base process and the proportion giving the correct answer decreased when the complexity of the theory applied increased:

- Most students (78\%) recognized a proton transfer process as Bronsted's model.

- $\quad 26 \%$ recognized the autoprotolysis of solvents $\left(\mathrm{SO}_{2}\right)$ as an acid-base process.

- Only $12 \%$ considered the electron transference as in Lewis' process.

- Less than $2 \%$ of the students applied all three theories.

Some Spanish university students explained that an electron transfer process (Lewis' model) or an autoprotolysis of solvents $\left(\mathrm{SO}_{2}\right)$ is not an acid-base process, for example, "It is not an acid-base process", "It is a redox process", or "It is not an acid-base process because there isn't $\mathrm{H}^{+}$or $\mathrm{OH}^{-}$or $\mathrm{H}_{3} \mathrm{O}^{+}$". Thus, as in many occasions mentioned by other authors (Drechsler 2007; Drechsler and Van Driel 2009; Zoller 1990), the BronstedLowry acid-base process is more recognized by students than other acid-base models. For us, this result is evidence that the university students did not transfer their knowledge about acid-base acquired to new situations, for example, the Lewis' acid-base electron transferences. 
(b) Applicability of acid-base models. As a consequence of the previous result, it was expected that most of the graduates in their secondary education teacher Civil Service examination would cite Arrhenius', Bronsted-Lowry's, and Lewis' models (data from research on 50 exams). Nevertheless, in approximately $15 \%$ of the cases, the description was wrong. Only $52 \%$ of the candidate teachers identified the boundaries of Arrhenius' model, three-quarters made no comment on the limitations of Bronsted-Lowry's theory, and none recognized that there might be limitations in Lewis' theory and what they explicitly consider is the currently accepted one (Jiménez-Liso 2000), similar to the results founded by Yalcin (2011) with Turkish candidate teachers. Previous omissions of the limits of applicability of the different acid-base theories are worrying as regards that, if they passed this exam, they would be qualified as secondary education teachers in Physics and Chemistry. They do not usually follow any continuous professional training as teachers, a fact that also occurs in other countries such as England, France, Finland, and Cyprus, and could affect the quality of teaching and the improvement of the education system (Evagorou et al. 2015).

Teachers must have knowledge about teaching scopes and limitations of different acid-base models; nevertheless, most of them had not developed teaching strategies for this issue and only a few teachers said that they usually discussed the use of models of acids and bases in their teaching (Drechsler and Van Driel 2008). Although they recognized some difficulties of the students such as confusion between models, only a few emphasized the different models of acids and bases (Alvarado et al. 2015; Drechsler and Van Driel 2008). Moreover, despite some teachers believing that most students do not understand the use of models, they tried to teach it anyway in order to help the best students in their learning, hoping other students understand that simple models are not the whole truth (Drechsler and Van Driel 2008).

\subsection{Consequence III: Misunderstanding About the Development of a Historical Model}

By presenting two or three theories together, the Lewis and Bronsted-Lowry definitions are just that — definitions - and the validity of one of them does not automatically negate the other (although it may expand the set of substances which are classed as acids). The conceptualfocused teaching mentioned above is insufficient because it comes from a purely theoretical perspective without any kind of application, reduced to the definitions instead of containing a clear explanation of their development (Cid Manzano and Dasilva Alonso 2012) and of the problems or phenomena that gave rise to new ideas.

The three favourite acid-base theories are presented as a collection of "agreed upon facts", so students memorize them without questioning their relationship with other scientific knowledge (Justi and Gilbert 1999a), and focusing on the products rather than on the processes of science.

There is clear evidence that many problems learners have arisen from acid-base theories confusion. When several theories of acid-base are presented together to students the scope to produce confusion is expanded, above all if most learners have a very limited notion of the role of models in science (Driver et al. 1996; Grosslight et al. 1991; Taber 2001).

The role of a model in science is related to developing a scientific understanding of some phenomena, explaining them and predicting other related phenomena, then applying the new knowledge to novel situations or contexts (Izquierdo-Aymerich and AdurizBravo 2003; Oh and Oh 2011). So, the reason for explaining three (or more) acid-base 
theories together is not related to scientific understanding of the phenomenon. The reasons for introducing the three most used acid-base models together appears to be twofold: firstly, conceptual survival (a concept from past chemical curricula that is retained in modern chemical curricula) and, secondly, to show the history of a chemistry concept in a narrative manner. Thus, the emphasis is focused on the differences between each concept, a fact that does not promote a proper understanding of science, instead of comprehending the conditions when the models were built and, consequently, the limitations they have. No advantage is taken of the opportunities to get the students to reflect on the nature of science through the history of acid-base theories. On the contrary, they usually develop a distorted image of science itself and of how it is carried out.

Before we discuss teaching acid-base models in the chemistry curriculum, it is necessary to clarify terminology. Acid-base concepts, definitions, theories, and models are often used as synonymous. Students' mistakes often arise due to the ambiguous use of the terminology (Jiménez-Liso and de Manuel Torres 2002). To avoid this difficulty, we have adopted acidbase models as the correct terminology to refer to the models that explain and predict phenomena proposed by Arrhenius, Bronsted, and Lewis, because we understand that the theories in which they are included are the ionic dissociation theory, solvents theory, and valence electron theory respectively.

Considering that curriculum materials shape teachers' practice and characteristics (as their knowledge or beliefs) and students' opportunities to learn in science (Davis et al. 2016; Pareja Roblin et al. 2018), in the next section, we try to identify activity sequences, firstly with an explicit NoS approach using the timeline of the historical development acidbase models.

\section{Explicit Approach to NoS Teaching}

As Burgin and Sadler (2016) mentioned, the prevalent model for teaching NoS in school has been referred to as the explicit/reflective approach (Lederman 2007). In this approach, the priority object of study is to teach the great consensus about the nature of science (tentativeness, creativity, ...) to avoid the main distorted views of science. Typical activities using this approach are discussions about a "paper towel investigation", about the "card exchange" (Cobern and Loving 2002), or about historical cases (readings or movies) (Aduriz-Bravo and Izquierdo-Aymerich 2009; Moreno et al. 2018) and scientific errors (Kipnis 2011) as a particular historical case or some historical controversies (Niaz 2009). All of these strategies for teaching are linked to some rationale, to educational purposes (Nouri et al. 2019). The acid-base timeline (Fig. 1) could link with the next curriculum purposes for specific educational levels (Table 1).

More interesting than improving acid-base content understanding are the opportunities to advance the understanding of nature of science content using certain moments of the acid-base timeline, for example, the story of what happened with acid-base models in 1923.

In 1923, Bronsted and Lowry proposed their explanations about acid and base behaviour. Both knew Arrhenius's model (1903) and a less famous one today: the solvent-solute model proposed by Franklin (1905). Some 21 years later, two researchers independently proposed a particular case of solvent model (proton model) where the water acts as solvent and its autoprotolysis as definition of acids (proton donor) or bases (accept protons). 
Table 1 Opportunities to improve the understanding of scientific content using acid-base historical models (or pre-models)

\begin{tabular}{lll}
\hline Model & Possible curriculum purpose & Educational level \\
\hline
\end{tabular}

Greek Ancient; Middle Age, for example, Al Practical purposes: observations, Razi (XVII c); Glauber ( $\left.{ }^{\dagger} 1670\right) \quad$ classifications...

Cooking pre-model (or Craft model in terms To increase the experiential knowledge of of de Vos and Pilot 2001)

Anthropomorphic model as is described by Justi and Gilbert (1999b)

Sour-acid salt is a simple body, acute in form, that ferments with alkalis and constitutes the essence of all mixtures. Acrid salt is a simple salt, with holes, that ferments with acids. Lemery's model on XVII c. (Taton 1964)

Affinity model based on acid-base properties. This model overcome the antagonism between acid and alkali (in opposition to the idea that acid was the universal agent) by Boyle in XVIIth century

Lavoisier model (1775) or Priestley model (1772): first composition models (de Vos and Pilot 2001) called as synthesis context

Dissociation model (from dissociation theory) by Arrhenius (1903)

Solvent model (based on solvent autoprotolysis; Franklin 1905).

Proton model (based on water autoprotolysis) given by Bronsted (1923) and Lowry (1923) independently

Pair electron model (based on electron valence theory of Lewis 1923) students abou the acid-base behaviour

To link with chemical change models expressed by students and with school science models such as "parts model" described by Acher et al. (2007) and their pivotal ideas like transformations and conservation of "parts"

To distinguish dilution (colour fading) and neutralization (Erduran 2007; Erduran and Kaya 2019, p. 40)

To explain the colour of a homemade indicator in the presence of an acid or a base and their change with the mixed using drawings

Chemical change as substantial change: acid-base properties can help students to recognize different substances before or after a chemical change

(Dominguez-Sales et al. 2007; Furió-Mas et al. 2007)

Linked with Lemery's model could be a good introduction for a simple chemical formulation

The introduction of these models is needed as a first conception to form the basis for an explanation of both the limitations in their applicability and also the advantages of the following models (de Berg 2011, 2014)

To link with Lemery's model, to introduce the "submicroscopic" level in chemical change and to explain other phenomena that are impossible with Lemery's model (i.e. effervescence (Drechsler 2007; Jiménez-Liso et al. 2018)

It is important that students recognize that, in this model, acid, base, neutralization, and strength are absolutes. A substance is an acid because it contains $\mathrm{H}^{+}$, independently of what it reacts with

The main purpose of this model is not to identify acid-base processes with aqueous processes

It explains all the phenomena and events in chemical analysis (i.e. titrations)

Lower secondary level

Lower secondary level

\section{Since lower} secondary level

\section{Since lower} secondary level

It introduces the concepts of equilibrium, reversibility, and the idea that acid, base, and strength are relative

This model involves a big jump from the previous model. It needs a paradigm change from proton model to electron model
University level

\section{Upper secondary} level

Upper secondary level 
Table 1 (continued)

\begin{tabular}{|c|c|c|}
\hline Model & Possible curriculum purpose & Educational level \\
\hline & $\begin{array}{l}\text { At university level, is necessary linking this } \\
\text { model to electron valence theory, to } \\
\text { molecular structure, to covalent bond, etc. } \\
\text { (Tarhan and Acar Sesen 2012) }\end{array}$ & \\
\hline $\begin{array}{l}\text { High pressures model (for reactions in high } \\
\text { pressure such as on geological process) } \\
\text { given by Lux and by Flood independently } \\
\text { (1939) }\end{array}$ & $\begin{array}{l}\text { Important to explain some geological } \\
\text { phenomena (Ottonello and Moretti 2004). }\end{array}$ & $\begin{array}{l}\text { University level } \\
\text { (chemistry or } \\
\text { geology } \\
\text { degrees) }\end{array}$ \\
\hline $\begin{array}{l}\text { Integrate model (electron is interchanged, } \\
\text { this model includes all chemical reactions } \\
\text { like the acid-base process) (Usanowitsch } \\
\text { 1939) }\end{array}$ & $\begin{array}{l}\text { The sole meaning of this model is to show } \\
\text { that there is only one chemical change } \\
\text { theory (and different models). All the } \\
\text { chemical reactions (redox, acid-base) are } \\
\text { included in this model. }\end{array}$ & $\begin{array}{l}\text { University level } \\
\text { (chemistry } \\
\text { degrees) }\end{array}$ \\
\hline $\begin{array}{l}\text { Hard-soft model (HSAB) by Pearson in } \\
1963 \\
\text { Thermodynamic parameters of HSAB model } \\
\text { by Drago in } 1966\end{array}$ & $\begin{array}{l}\text { Based on Lewis' model, giving it a criterion } \\
\text { about strength very it is most useful to } \\
\text { organic chemical mechanism }\end{array}$ & $\begin{array}{l}\text { University level } \\
\text { (chemistry } \\
\text { degrees) }\end{array}$ \\
\hline
\end{tabular}

We can use the original papers from Bronsted, Lowry, and Lewis to help them to answer the next questions that we can ask to our high school students (or university students):

- Why does emerge a limited model (proton model, Bronsted-Lowry model) after a broader model (Franklin model)?

We want to scaffold "the epistemic value of simplicity, referred to as Ockham's razor, meaning that the simplest applicable model is the most elegant and the best" (Rollnick 2019, p. XIV). The solvent model proposed by Franklin (1905) was known by Bronsted and Lowry but they only used the water as solvent, so for solving their problems, they did not need a broader model and they specify it on a model more simple but more useful. In fact, it is the most widely used and known today because most acid-base reactions are aqueous.

- A Danish researcher (Varde, Denmark) (Bronsted 1923) and the same year that (Lowry 1923) from Bradford (UK) propose the same proton model, how do you think it was possible for two researchers in different countries (without knowing each other) to propose an identical model?

Perhaps in our digital era this scenario is unthinkable: Two researchers producing identical researches without any previous contact, but in 1923, they heard from each other when they read the papers already published in two different journals. The scientific community recognized the merit of both of them and, thereafter, their model was named Bronsted-Lowry. What circumstances led both to propose the same theory? Bronsted (1923) started from the dissociation electrolytic theory of Arrhenius, which initially does not call into question his idea of acid $\left(\mathrm{A} \rightarrow \mathrm{B}+\mathrm{H}^{+}\right)$ and for which he tries to find a better definition of base: "It is the purpose of the present small contribution to show the advantages that come from a modified 
definition of a base" (Bronsted 1923, p. 718), specifically the difficulties in explaining the basicity of ammonia:

If we accept scheme $\left(\mathrm{NH}_{4}{ }^{+}+\mathrm{OH}^{-}<===>\mathrm{NH}_{4} \mathrm{OH}\right)$, as a suitable expression for characterizing bases, we will be forced to give a special definition of a base for each special solvent. However, in principle, acid and basic properties are independent of the nature of the solvent, and the concepts of acids and bases are in fact of such a general character that we must consider it a necessary requirement of these concepts in general to formulate a pattern independent of the nature of an arbitrary solvent (Bronsted 1923, p. 719)

and ends by concluding:

The equilibrium formulated in scheme (1) between hydrogen ion and the corresponding acid and base can be called a simple acid-base equilibrium. By mixing two simple systems, a double acid-base system and an acid-base equilibrium result that can always be formulated as follows:

$$
\operatorname{acid}_{1}+\text { base }_{2}<===>\text { acid }_{2}+\text { base }_{1}
$$

This equilibrium includes a number of important reactions such as neutralization, hydrolysis, indicator reactions, etc. (Bronsted 1923, p. 728)

On a different path, Lowry (1923) knew the electron valence theory of Lewis (1923) and relied on it to distinguish two types of chemical affinity (polar and non-polar) and their links in organic and inorganic substances, which led to the need of proposing $\mathrm{H}_{3} \mathrm{O}^{+}$as what is exchanged in acid-base reactions overcoming Arrhenius $\mathrm{H}^{+}$proposal, the difficulty of the basic character of $\mathrm{NH}_{3}$ and the relative character of strong or weak acids depending on which substance they react with (Fig. 3).

- With the previous knowledge, students are willing to answer one last question: How do you think two models emerged in 1923 from three different people working independently and in different paradigms (proton or electron paradigms)? 1923 was a good year for the acid-base historical development. Lewis (1923) also raised his electron model (Fig. 4) under a totally different paradigm (based on his electron valence theory) and to solve a problem not contemplated by his contemporaries: acid-base behaviour in reactions without solvent, for example, in gas reactions.

Discussing with upper secondary students (or university students) these acid-base moments of a broad timeline, we could challenge the accumulative-linear and erroneous image of science.

For university chemistry or geology degree students, similar questions could be posed using the 1939 and Lux-Flood models for reactions in high pressure such as on geological process (without any dissolution). And also for university chemistry students (pre- and post-graduated), another interesting controversy could be the qualitative and quantitative chemical approaches (Chamizo 2018) between Pearson (1963) who proposed empirically his hard and soft acid-base model and Drago (1973).

\section{Implicit Approach to NoS Teaching}

\subsection{Inquiry-Based Teaching Proposal}

Barrow (2006) described inquiry firstly as an epistemic practice (Kelly 2008), secondly, as scientific skills that students should develop, and finally as a teaching approach. We remain 
'The effect of mixing hydrogen chloride with water is probably to provide an acceptor for the hydrogen nucleus so that the ionisation of the neid only involves the transfer of a proton from one octet to mother.

$$
\begin{aligned}
& : \ddot{\mathbf{C l}}: \mathbf{H}+\mathbf{H}: \ddot{\mathbf{O}}: \mathbf{H} \rightarrow: \ddot{\mathbf{C l}}:+\mathbf{H}: \ddot{\mathbf{O}}: \mathbf{H} \\
& \quad \text { or } \mathrm{Cl} \mathrm{H}+\mathrm{H}_{2} \mathrm{O} \rightarrow \ddot{\mathrm{C}}+\stackrel{+}{\mathrm{O}} \mathrm{H}_{3}
\end{aligned}
$$

5. A base is hest described as an acceptor of liyctrogen nuclei. Fiven in the case of strong acirls the addition of water, acting as an aceeptor, is necded in order to develop acidity. A basic aceeptor is also needed to promote the migration of a hydrogen nucleus in nitrocamphor and in the two forms of ethyl acetoacetate.

Fig. 3 Extracts from Lowry's (1923) paper (pp. 44 and 47)

with this last meaning of inquiry to propose an instructional sequence of activities. As there are a multitude of research proposals (Pedaste et al. 2015), we have specified our teaching approach in a cycle (Fig. 5 in orange) to connect it with the modeling cycle (Fig. 5 in green) proposed by Couso (2020) and Couso and Garrido-Espeja (2017).

In the acid-base domain, reactions can be followed with indicators from daily life such as red wine. When we use the red cabbage as an acid-base indicator, we generally emulate Boyle's descriptive pre-model in order to recognize the acid-base nature of some daily life products. In this way, we create (as Boyle did) a classification of acid, neutral, or basic substances.

We transform these hands-on activities about the acid-base classification to an inquirybased teaching where the steps will be easily recognizable by our students so that they become aware of how they have learned (learning and emotions self-regulation) and, therefore, can make an explicit debate about the phases of the inquiry, how they help to learn, and what emotions they felt during this sequence (step 7 in cycle orange, Fig. 5).

To do this, we begin with a familiar problem (chewing gum TV advertisement ${ }^{1}$ stops the acid attack, strengthens the tooth enamel and helps to keep your teeth strong and healthy while in the image we can show that raise the $\mathrm{pH}$ of the mouth to prevent the formation of cavities (JiménezLiso et al. 2018) that engages students to explain their personal ideas: chewing gum is the opposite of acids generated by food in the mouth, the TV ad does not tell the truth and the gum does nothing, warms and destroys the acids, more saliva is generated or the gum traps the remains of food. The key moment in this sequence is the students' proposals for designs of experiments that allow them to find evidence to confirm or reject their hypotheses.

The experimental designs raised by our students facilitate the discussion about the usefulness of the designs (what did they measure? With what did they check?). For instance, some students proposed to put some food in a glass with water (to simulate the mouth) along with the gum and measure with $\mathrm{pH}$ paper, to which another group responded that they did not check the "before" and the "after" adding chewing gum, that is, the effect of chewing gum. Others suggested sucking $\mathrm{pH}$ paper after eating and again after chewing gum (López-Banet et al. 2021).

Taking measurements with a $\mathrm{pH}$ meter can be a conflict for the students with their expectations, both because the chewing gum does not raise the $\mathrm{pH}$ of the acid-dissolution (mouth simulation) and neither does adding water (dilute). This opens the option of deepening the mathematical conflict that involves a linear scale ( $\mathrm{pH}$ values of 1-14) versus a logarithmic scale (which means $\mathrm{pH}$ ) asking how much water would be necessary to raise the value by one point (López-Banet et al. 2021).

\footnotetext{
${ }^{1}$ https://youtu.be/s9mODx3eru4
} 
up hydrogen ion would be more general than the one that we used before, but it will not be universal. Another definition of acid and base in any given solvent would be the following: An acid is a substance which gives off the cation or combines with the anion of the solvent; a base is a substance which gives off the anion or combines with the cation of the solvent. So potassium amide is a base in ammonia, while potassium chloride would likewise be called a base in liquid hydrochloric acid.

Even this very broad definition is not entirely satisfactory. We are inclined to think of substances as possessing acid or basic properties, without having a particular solvent in mind. It seems to me that with complete generality we may say that $a$ basic substance is one which has a lone pair of electrons which may be used to complete the stable group of another atom, and that an acid substance is one which can employ a lone pair from another molecule in completing the stable group of one of its own atoms. In other words, the basic substance furnishes a pair of electrons for a chemical bond, the acid substance accepts such a pair.

Fig. 4 Extract from electron valence theory book (Lewis 1923, p. 142)

However, as Osborne (2014) mentioned, hands-on activities, such as the acid-base classification using red cabbage indicator, are not normally accompanied by an interpretation or explanation of the phenomena. In our inquiry-based sequence, students built essential descriptive knowledge (acid-base reactions vs dilution with water or saliva) so that they now recognize the need to seek an explanatory model perfect to start the modeling cycle (Fig. 5).

\subsection{Model-Focused-Teaching Proposal for Lower Secondary Level}

The use of red cabbage as an acid-base indicator, often carried out by students aged up to 16 years old, is not accompanied by its possible explanation using models, keeping the explanation for higher levels (16-18 years old and university level). In this sense, the first

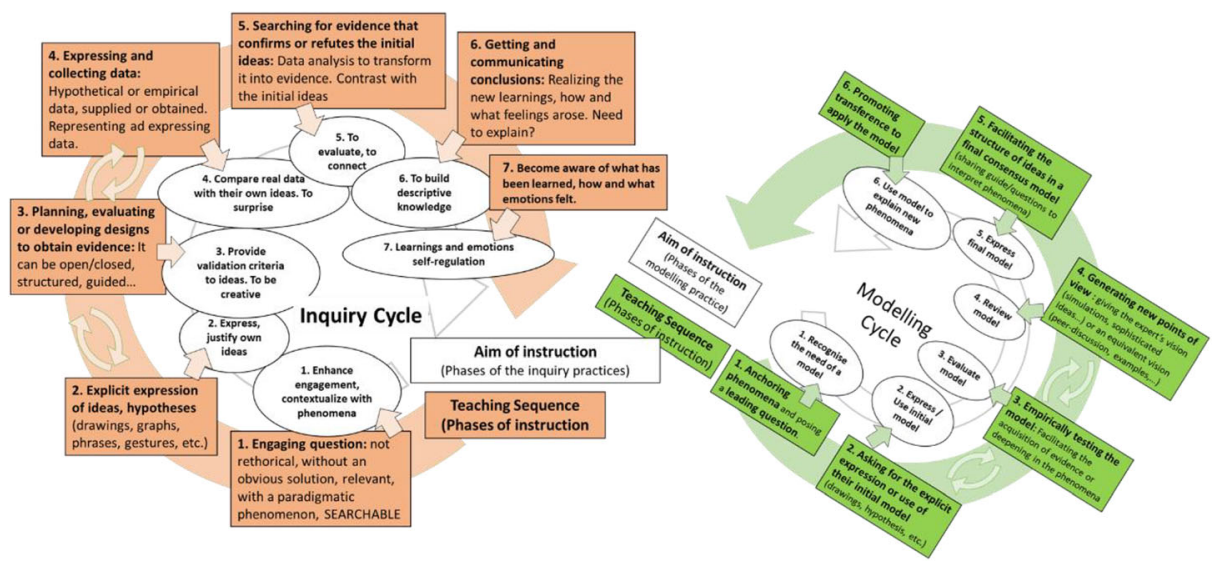

Fig. 5 Cycles of inquiry (in orange; Jiménez-Liso et al. 2019 and Jiménez-Liso 2020) and modeling (in green; Couso 2020; Couso and Garrido-Espeja 2017) of teaching sequences and their aims of instructions (phases of the scientific practices) 
introduction of an explanatory model is presented for 16-18-year-old students and, generally, Arrhenius or Bronsted-Lowry's model is used to present acid-base processes disconnected from those activities carried out (or not) during previous years (Jiménez-Liso et al. 2010). Therefore, if we focus the contents exclusively on the phenomenon and the identification of substances, we are only increasing the students' experiential field, but not their ability to explain phenomena they observe or to foresee what is going to happen in new situations.

Some hands-on activities about properties of acids and bases emphasize the teaching and learning of chemical knowledge through models and modeling by the formulation, evaluation, and revision of chemical models. When we ask students to express what they think happens "inside" by adding a base to an acid and observing changes in the colour of the indicator or changes in $\mathrm{pH}$ values, their initial models are unsatisfactory for some explanatory reasons (steps 1 and 2 in modelling cycle; Fig. 5 in green; Couso 2020; Couso and Garrido-Espeja 2017). Students may have difficulties when it comes to expressing these initial models through drawings, most often represent non-explanatory circles, and only some of them point differently to acids or bases indicating that it is acidic when acids "predominate" over the bases and vice versa (López-Banet et al. 2021). Despite these difficulties of the students in explaining "what happens inside", we cannot consider these initial models as students' alternative conceptions described in Section 5.1 for two reasons: firstly, students' alternative conceptions were the product of punctual and "academicist" knowledge and, secondly, the difficulty for the initial models to be explanatory is the initial step to become aware of the need to build a model, that is an idea that helps explain a phenomenon (change of colour of acid-base reactions with indicator) and to predict new ones (for example the bubbles when we add bicarbonate to the vinegar).

Students are expected to relate properties of a substance to its shapes, in a similar way to Nicolas Lemery's model (Erduran 2007; Erduran and Kaya 2019). This seventeenth-century scientist explained that acids consist of keen particles that prick the tongue when they are tasted, differing both in length and in mass from one another. On the other hand, alkalis have pores where the acid points entering into do strike and divide them when oppose the motion of acids. So the difference of the points in acid substances is the cause why some acids can penetrate and dissolve well certain sort of mixts (Lémery 1697). Our version of this model is a PACMAN model (Jiménez-Liso et al. 2018) suggested sometimes by some of our students. They are able to reason as ancient scientist used to and to build their own explanations in a similar way about what happens in a microscopic level by means of descriptions of the reality (macroscopic level) and their intuitive thoughts.

This anthropomorphic model is already useful for students because it explains acid-base phenomena but it needs to be refined (steps 3 and 4 of the modeling cycle) because it does not serve them to explain a well-known experiment: why the balloon is inflated by adding bicarbonate to the vinegar. When students must construct a model to explain this precise knowledge of reality (what happens with the balloon), they introduce partial modifications to their useful models (Lemery or PACMAN model with triangles as acid) such as "bow ties" that fly when the PACMAN eats the triangles, and they argue on its validity (or not) according to the descriptive knowledge they already have. This process leads them to identify the insufficiency of their initial models, the useful of PACMAN model and its limits, and the need for refinement to explain the production of gases in acid-base processes. Figure 6 shows other alternative model based on the fighting idea to form a structure together that explain gases formation in an acid-base reaction, done by other students.

As it is necessary to help students to comprehend the nature of models, a possible strategy could be introducing an explanation similar to that one mentioned as past scientists did. The 


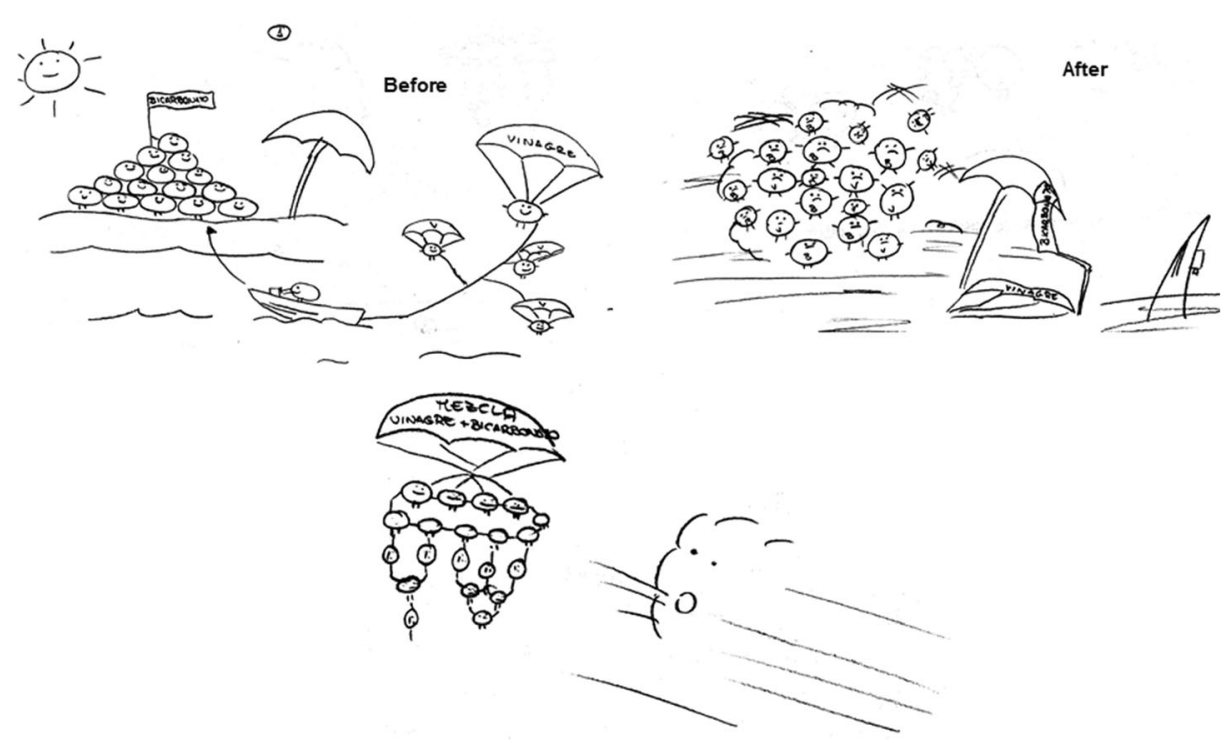

Fig. 6 Fighting idea to form a structure together that explain gases' formation in acid-base processes

activities previously mentioned encourage pupils to express their own ideas, giving opportunities to evaluate and restructure them, in order to pass from their initial to more scientifically valid conceptual schemes ones. For instance, pupils draw representations trying to explain the way they perceive some common substances and they described their models in class to share their ideas, as drawing "bubbles" in acids and less bubbles or no bubbles in the base substances (Erduran 2003).

Lemery, PACMAN or fighting models are very anthropomorphic. However, these models allow quick connection with the chemical formulation and the Arrhenius model (Fig. 7 from Jiménez-Liso et al. 2018).

\subsection{Connected Key Aspects of Acid-Base Model-Focused Teaching for Upper Secondary Level (or University Degrees)}

As Couso (2020) mentioned, a model-focused teaching would be to put students in the situation of building themselves "adequate enough" explanations, in other words, to construct school-based scientific models to describe the behaviour of the world and to comprehend how it works (Aduriz-Bravo and Izquierdo-Aymerich 2009; Izquierdo-Aymerich 2000). Instead of learning the models as the result of the scientific activity, it would be enough to focus on some specific big ideas (Harlen 2010) or key ideas (National Research Council 2012) that have the potential to explain a lot of different phenomena (Izquierdo-Aymerich and Aduriz-Bravo

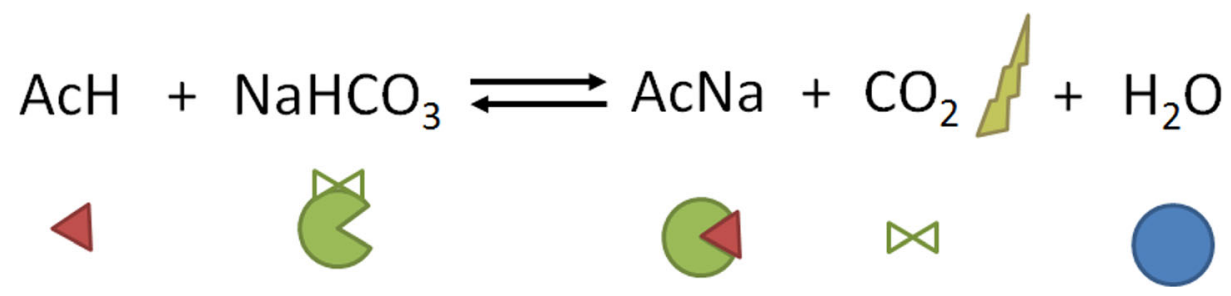

Fig. 7 Correspondence between the PACMAN model elements and chemical formulation (Jiménez-Liso et al. 2018) 
2003). Thus, a model-based teaching approach offers instructional strategies for improving conceptual learning in science education (Shen and Confrey 2007) and permits students go beyond the idea of models as reproduction, allowing them to reach the vision that the relationship between model, experiment, and reality is dynamic and evolutionary (Tasquier et al. 2016).

In order to build a school science using more sophisticated models for upper secondary or university levels, as in our case, we talk about the model associated with phenomena using the concrete term "key connected aspects", which should emphasize:

- The purposes of each model: for example, Arrhenius' model is an explanation based on the classification of substances in acids or bases and their reactions, Bronsted-Lowry's model is based on equilibrium, and Lewis' model focus on a different paradigm, the electron theory. We want to emphasize on this idea because it changes the acid-base view, from the conceptual-focused teaching (Fig. 1) because we defined acid that contains $\mathrm{H}^{+}$ (Arrhenius) or that donates $\mathrm{H}_{3} \mathrm{O}^{+}$(Bronsted-Lowry) to a new view with an explanatory power of both models, which in the case of Arrhenius explains reactions between substances and Bronsted-Lowry explains equilibrium, balances, and, therefore, their reversibility (Fig. 8), as we will see below.

- Acid-base characteristic from each scientific model: our perceptions about acid-base definitions given in Fig. 1 change from acid-base as substances to the absolute acid and base properties based on their chemical composition in Arrhenius' model (Fig. 8, left), from the acid-base pairs conjugated to the relative properties of substances in BronstedLowry's model (Fig. 8, right), or from acid-base as accept-donor pair of electrons (the electron paradigm) to its possibilities to explain solvent absence in Lewis' model. These decisive acid-base characteristics are connected to the models' educational purposes

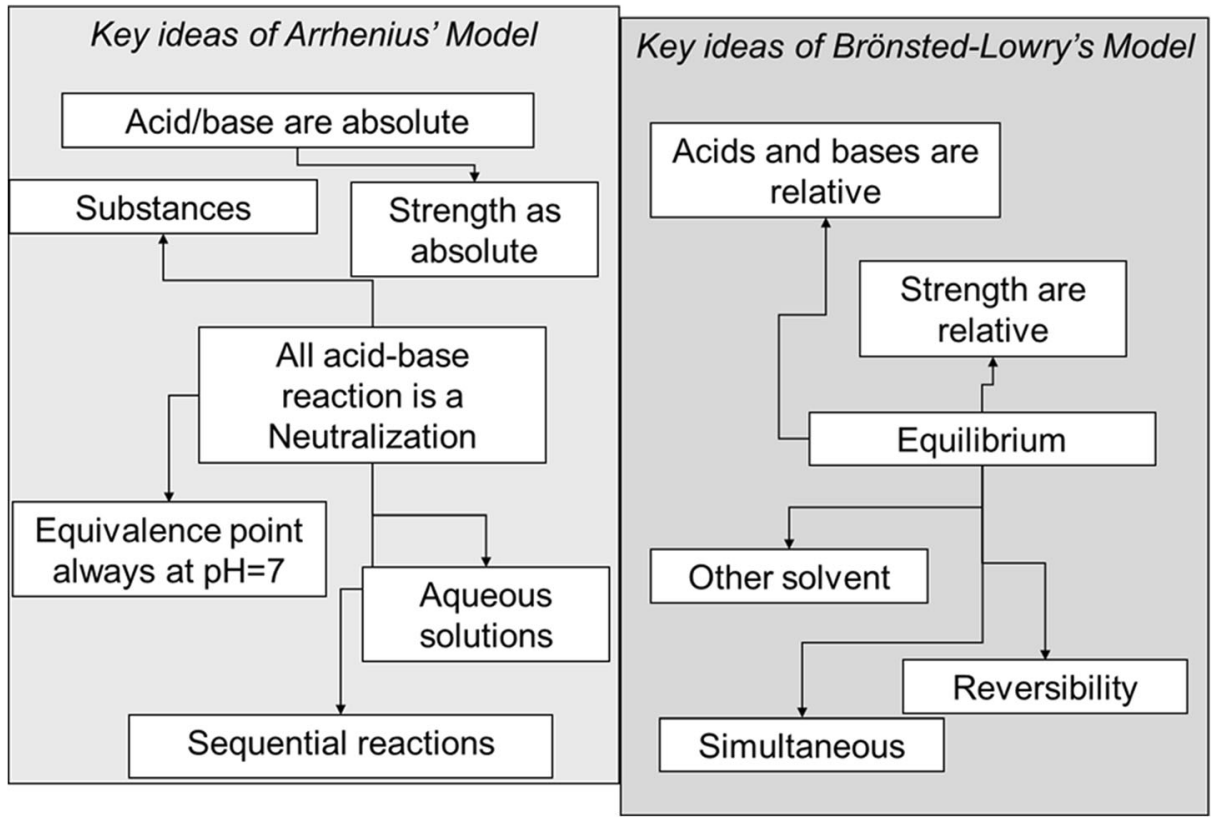

Fig. 8 Connected key aspects of Arrhenius' and Bronsted-Lowry's models 
through a simplification of the historical scientific consensus models and it explains why some historical models can still be used to explain some phenomena (Table 1). The comparison and contrast of these key features, the nature, and purposes of models can be addressed in the teaching.

- Scope, boundaries, and explanatory power: for example, Bronsted-Lowry's model can explain not only the reason why a reaction between a strong acid and a weak base produces a $\mathrm{pH}<7$ solution without using hydrolysis concept but also that the reaction between a base and water is possible and that two acids (one stronger than other) can react (however a weak acid, according to Arrhenius' classification, reacts like a base). These explanations are not possible using Arrhenius' model.

It would not be prudent to discard a model that is easy to understand and is well applicable in many cases (Ockhams razor (Rollnick 2019). For instance, many chemical reactions occur in aqueous solutions because many compounds have hydrogen or hydroxide ions. Thus, teaching the Arrhenius concept is important for the purpose of promoting the recognition of the meaning of the acid-base characteristic from this scientific model in science learning. However, for this purpose, the introduction of new concepts needs to be followed in order to overcome the limitations of the Arrhenius concept (Paik 2015). On the other hand, the key ideas from Bronsted-Lowry model emphasize five concepts: equilibrium, reversibility, simultaneous, and the relative strength of acids and bases, both in aqueous and non-aqueous solvent (Fig. 8). When acid-base reactions occur without solvent, for example, gases reactions, neither Arrhenius' model nor that Bronsted-Lowry's model serves to explain them, so we need other models such as Lewis' electron valance model or Lux-Flood model for geological hard pressure acid-base reactions.

\section{Conclusions}

The arguments put forward in this paper might convince teachers to deepen their teaching of acid-base processes, at all possible educational levels, by taking advantage of the presence of historical development in upper secondary and to cover the need to advance it to primary or lower secondary levels by the arguments involving the presence of acids and bases in our daily lives and on solving socio-scientific issues about health or the environment.

The extensive bibliography on alternative conceptions at all educational levels (including teachers and candidates to be) justify the need for a change in the usual way of presenting it that focuses on the presentation of definitions on acid, base, theirs reactions, $\mathrm{pH}$, etc., in two or three "theories" presented together. This fragment of the history of science that survives in the current curriculum (in upper secondary and chemistry degree, university level) offers a very good opportunity for NoS teaching without overloading the already extensive and concentrated chemistry curriculum.

Thus, the main aim of traditional acid-base teaching is to learn the main concepts by means of conceptual-focused teaching and it is very far from making sense to the students, because it makes them look at the bricks and not in their usefulness as part of a larger and more beautiful castle (meaningful) and useful. Inquiry-based teaching (Section 7.1) and the model-conceptual teachings that were exemplified in this paper (Sections 7.2 and 7.3) provide implicitly a chance to reflect on how science is constructed. 
Whereas the conceptual-focused teaching only explains definitions and emphasizes on descriptions about behaviours (not always coordinated), model-focused teaching emphasizes on explanations, interpretations, and predictions (Stefani and Tsaparlis 2009). In this way, students should learn to use each model within its application domain to address different phenomena. Applicability of acid-base models should be better understood, and knowledge of acid-base models would be transferred to new situations, for example, to recognize a new process as an acid-base reaction.

In this paper (Section 7.3), we proposed that considering models include key ideas connected in a particular way they provide coherence to concepts. Both approaches are in conflict with each other, so this dual treatment is discussed: teaching isolated ideas in a conceptual-focused teaching or the relationship between connected key aspects through a model-focused teaching.

We have attempted to show the differences between NoS teaching approaches through several sequences of activities. First, one sequence with an explicitly NoS approach, as Lederman (2007) points as desirable, and then, three implicit approaches, similar to Duschl and Grandy's (2013) recommendations. These four sequences can help teachers to perceive the potential results of choosing one of those treatments in acid-base lessons, according to their own teaching goals. Also, this concretion in sequences of activities, which is the fundamental tools for teachers to teach, can encourage them to teach acid-base models in a way closer to the recommendations of NoS researchers.

As we pointed out in the introduction, by specifying the implicit-explicit debate in several sequences of activities, we are also offering, for science teacher training, a theoretical learning progression. Pre-service or in-service teachers in training could live inquiry and modeling sequences since Lemery to the more sophisticated models and it allows to place the implicit sequence one after this lineal progression to make explicit the awareness of how the science is built. Finally, as an agenda for future work, we could follow the steps outlined in this paper in order to develop an evaluation study about the efficiency of consensus NoS understandings of each implementation of our implicit, explicit-IBSE, explicit-modeling sequences, using frameworks such as Burgin and Sadler (2016).

Acknowledgements This work would not have been possible without the inspired discussions with Esteban De Manuel (Rut's PhD supervisor) and John T. Leach and the participation of IES Murgi students, their teachers Lucía, Isabel and Carmen.

Funding Information This work has been partially financed by the projects EDU2017-82197-P and PGC2018097988-A-I00 of the Ministry of Science and Innovation (MCI) of Spain, the State Research Agency (AEI) and the European Regional Development Fund (FEDER), and with a visiting scholar in the University of Exeter PRX19 / 00364 of the Ministry of Education of the Government of Spain.

\section{Compliance with Ethical Standards}

Conflict of Interest No potential conflict of interest was reported by the authors.

\section{References}

Acher, A., Arcá, M., \& Sanmarti, N. (2007). Modeling as a teaching learning process for understanding materials: a case study in primary education. Science Education, 91(3), 398-418. https://doi.org/10.1002/sce.

Aduriz-Bravo, A., \& Izquierdo-Aymerich, M. (2009). A research-informed instructional unit to teach the nature of science to pre-service science teachers. Science and Education, 18(9), 1177-1192. https://doi.org/10.1007 /s11191-009-9189-3. 
Alvarado, C., Cañada, F., Garritz, A., \& Mellado, V. (2015). Canonical pedagogical content knowledge by CoRes for teaching acid-base chemistry at high school. Chemical Education Research and Practice, 16(3), 603-618. https://doi.org/10.1039/C4RP00125G.

Arrhenius, S. (1903). Development of the theory of electrolytic dissociation. Nobel Lecture. http://atom. uwaterloo.ca/CHEM/History/arrheniuslecture.pdf.

Banerjee, A. C. (1991). Misconceptions of students and teachers in chemical equilibrium. International Journal of Science Education, 13(4), 487-494. https://doi.org/10.1080/0950069910130411.

Barrow, L. H. (2006). A brief history of inquiry: from Dewey to standards. Journal of Science Teacher Education, 17(3), 265-278. https://doi.org/10.1007/s10972-006-9008-5.

Bronsted, J. N. (1923). Some remarks on the concept of acids and bases. Recueil des Travaux Chimiques des Pays-Bas, 42(8), 718-728. https://doi.org/10.1002/recl.19230420815.

Burgin, S. R., \& Sadler, T. D. (2016). Learning nature of science concepts through a research apprenticeship program: a comparative study of three approaches. Journal of Research in Science Teaching, 53(1), 31-59. https://doi.org/10.1002/tea.21296.

Cavallo, A. (2007). Draw-a-scientist / mystery box. Science and Children, 45(3), 37-39 https://search.proquest. com/openview/00cbd00e0fec0a79bcecc4501 468 ea $8 / 1$ ?pq-origsite $=$ gscholar \&cbl $=41736 \&$ casa token $=$ G R b v r n J 7 M k 8 A A A A A : 7 t d M J u S B 2 M o z j g p E M 5 L n 8 hJbzLHxVgFKNlJZGpgZudDoKzwuOfqdjZTcNtctTzqJwvd3VtR4kk43.

Chamizo, J. A. (2018). Química General. Una aproximación histórica (Vol. 1). D.R. UNAM. https://doi. org/10.22201/fq.18708404e.2019.3.70007.

Cid Manzano, R., \& Dasilva Alonso, G. (2012). Estudiando cómo los modelos atómicos son introducidos en los libros de texto de Secundaria [Analyzing how Atomic Models are being introduced in Secondary School textbook]. Revista Eureka Sobre Enseñanza y Divulgación de Las Ciencias, 9(3), 329-337. https://doi. org/10.25267/Rev_Eureka_ensen_divulg_cienc.2012.v9.i3.02.

Cobern, W. W., \& Loving, C. C. (2002). The card exchange: introducing the philosophy of science. In W. F. McComas (Ed.), The nature of science in science education: rationales and strategies (pp. 73-82). Netherlands: Springer. https://doi.org/10.1007/0-306-47215-5_4.

Couso, D. (2020). Aprender ciencia escolar implica construir modelos cada vez más sofisticados de los fenómenos del mundo [Learning school science involves building increasingly sophisticated models of world phenomena]. In D. Couso, M. R. Jimenez-Liso, C. Refojo, \& J. A. Sacristán (Eds.), Enseñando ciencia con ciencia (pp. 70-81). Penguin Random House Grupo Editorial https://www.fecyt. es/es/publicacion/ensenando-ciencia-con-ciencia.

Couso, D., \& Garrido-Espeja, A. (2017). Models and modelling in pre-service teacher education: why we need both. In K. Hahl, K. Juuti, J. Lampiselkä, A. Uitto, \& J. Lavonen (Eds.), Cognitive and affective aspects in science education (pp. 245-261). Springer. https://doi.org/10.1007/978-3-319-58685-4_19.

Cros, D., Maurin, M., Amouroux, R., Chastrette, M., Leber, J., \& Fayol, M. (1986). Conceptions of first-year university students of the constituents of matter and the notions of acids and bases. European Journal of Science Education, 8(3), 305-313. https://doi.org/10.1080/0140528860080307.

Cros, D., Chastrette, M., \& Fayol, M. (1988). Conceptions of second year university students of some fundamental notions in chemistry. International Journal of Science Education, 10(3), 331-336. https://doi.org/10.1080/0950069880100308.

Davis, E. A., Janssen, F. J. J. M., \& Van Driel, J. H. (2016). Teachers and science curriculum materials: where we are and where we need to go. Studies in Science Education, 52(2), 127-160. https://doi.org/10.1080 /03057267.2016.1161701.

de Berg, K. C. (2011). Joseph Priestley across theology, education, and chemistry: an interdisciplinary case study in epistemology with a focus on the science education context. Science \& Education, 20(7), 805-830. https://doi.org/10.1007/s11191-010-9270-y.

de Berg, K. C. (2014). International handbook of research in history, philosophy and science teaching. In M. Matthews (Ed.), International handbook of research in history, philosophy and science teaching (pp. 317341). Springer. https://doi.org/10.1007/978-94-007-7654-8.

de Vos, W., \& Pilot, A. (2001). Acids and bases in layers: the stratal structure of an ancient topic. Journal of Chemical Education, 78(4), 494. https://doi.org/10.1021/ed078p494.

Demircioğlu, G., Ayas, A., \& Demircioğlu, H. (2005). Conceptual change achieved through a new teaching program on acids and bases. Chemistry Education Research and Practice, 6(1), 36-51. https://doi. org/10.1039/B4RP90003K.

Domènech Calvet, A. M., Máquez Bargalló, C., Roca Tort, M., \& Marbà-Tallada, A. (2015). La medicalización de la sociedad, un contexto para promover el desarrollo y uso de conocimientos científicos sobre el cuerpo humano [The medicalization of society as a context for promoting the development and use of scientific knowledge related to the hu]. Enseñanza de Las Ciencias. Revista de Investigación y Experiencias Didácticas, 33(1), 101-125. https://doi.org/10.5565/rev/ensciencias.1358. 
Dominguez-Sales, M. C., Furio-Mas, C., \& Guisasola, J. (2007). Learning from the history and philosophy of science: deficiencies in teaching the macroscopic concepts of substance and chemical change. In R. Pinto \& D. Couso (Eds.), Contributions from science education research (pp. 249-259). Springer. https://doi. org/10.1007/978-1-4020-5032-9_19.

Drago, R. S. (1973). Pearson's quantitative statement of HSAB [hard-soft acid-base]. Inorganic Chemistry, 12(9), 2211-2212. https://doi.org/10.1021/ic50127a063.

Drechsler, M. (2007). Models in chemistry education. A study of teaching and learning acids and bases in Swedish upper secondary schools [Karlstad University]. http:/www.diva-portal.org/smash/get/diva2:6511 /FULLTEXT01.pdf

Drechsler, M., \& Van Driel, J. (2008). Experienced teachers' pedagogical content knowledge of teaching acidbase chemistry. Research in Science Education, 38(5), 611-631. https://doi.org/10.1007/s11165-007-9066-5.

Drechsler, M., \& Van Driel, J. (2009). Teachers' perceptions of the teaching of acids and bases in Swedish upper secondary schools. Chemical Education Research and Practice, 10(2), 86-96. https://doi.org/10.1039/B908246H.

Driver, R., Learch, J., Millar, R., \& Scott, P. (1996). Young people's images of science. Buckingham: Open University Press. https://doi.org/10.1088/0031-9120/31/3/023.

Duschl, R. A., \& Grandy, R. (2013). Two views about explicitly teaching nature of science. Science \& Education, 22(9), 2109-2139. https://doi.org/10.1007/s11191-012-9539-4.

Erduran, S. (2001). Philosophy of chemistry: an emerging field with implications for chemistry education. Science \& Education, 10(Butterfield 1949), 581-593. https://doi.org/10.1023/A:1017564604949.

Erduran, S. (2003). Examining the mismatch between pupil and teacher knowledge in acid-base chemistry. School Science Review, 84(308), 81-88.

Erduran, S. (2007). Bonding epistemological aspects of models with curriculum design in acid-base chemistry. In M. Izquierdo, A. Caamaño, \& M. Quintanilla (Eds.), Investigar en la enseñanza de la química. Nuevos horizontes: contextualizar y modelizar. Ponencias (Universita, pp. 41-72). Universitat Autonoma Barcelona. http://edumat.uab.cat/didactica/files/compartits/28.pdf

Erduran, S., \& Kaya, E. (2019). In S. Erduran \& E. Kaya (Eds.), Transforming teacher education through the epistemic core of chemistry. Springer. https://doi.org/10.1007/978-3-030-15326-7.

Evagorou, M., \& Osborne, J. (2013). Exploring young students' collaborative argumentation within a socioscientific issue. Journal of Research in Science Teaching, 50(2), 209-237. https://doi.org/10.1002/tea.21076.

Evagorou, M., Dillon, J., Viiri, J., \& Albe, V. (2015). Pre-service science teacher preparation in Europe: comparing pre-service teacher preparation programs in England, France, Finland and Cyprus. Journal of Science Teacher Education, 26(1), 99-115. https://doi.org/10.1007/s10972-015-9421-8.

Franklin, E.C. (1905). Reactions in liquid ammonia. Journal of the American Chemical Society. 27(7), 820-851. https://pubs.acs.org/doi/pdf/10.1021/ja01985a002.

Furió-Mas, C., Calatayud, M. L., \& Bárcenas, S. L. (2007). Surveying students' conceptual and procedural knowledge of acid-base behavior of substances. Journal of Chemical Education, 84(10), 1717-1724. https://doi.org/10.1021/ed084p1717.

Garnett, P. J., Garnett, P. J., \& Hackling, M. W. (1995). Students' alternative conceptions in chemistry: a review of research and implications for teaching and learning. Studies in Science Education, 25(1), 69-96. https://doi.org/10.1080/03057269508560050.

Garrido-Espeja, A., \& Couso, D. (2017). Models and modelling as a training context: what are pre-service teachers' perceptions? https://pdfs.semanticscholar.org/68bf/832ad16a69a28224519cd48b7fc3706c4f69.pdf.

Gericke, N. M., \& Hagberg, M. (2010). Conceptual incoherence as a result of the use of multiple historical models in school textbooks. Research in Science Education, 40(4), 605-623. https://doi.org/10.1007/s11165-009-9136-y.

Grosslight, L., Unger, C., Jay, E., \& Smith, C. L. (1991). Understanding models and their use in science: conceptions of middle and high school students and experts. Journal of Research in Science Teaching, 28(9), 799-822. https://doi.org/10.1002/tea.3660280907.

Harlen, W. (2010). Principles and big ideas of science education. In Association for Science Education. 9780 863574313.

Hoe, K. Y., \& Subramaniam, R. (2016). On the prevalence of alternative conceptions on acid-base chemistry among secondary students: insights from cognitive and confidence measures. Chemistry Education Research and Practice, 17(2), 263-282. https://oi.org/10.1039/C5RP00146C.

Izquierdo-Aymerich, M. (2000). Fundamentos epistemológicos [ Epistemological foundations]. In P. Perales \& F. J. y Cañal (Eds.), Didáctica de las ciencias experimentales: Teoría y práctica de la enseñanza de las ciencias [Didactics of experimental sciences: theory and practice of science education] (pp. 35-64). Marfil.

Izquierdo-Aymerich, M., \& Aduriz-Bravo, A. (2003). Epistemological foundations of school science. Science \& Education, 12, 27-43. https://doi.org/10.1023/A:1022698205904.

Jiménez-Liso, M. R. (2000). Contenidos relacionados con los procesos ácido-base: diagnóstico y propuestas didácticas al nivel universitario [Contents related to the acid-base processes: diagnosis and didactic proposals at the university level]. $\mathrm{PhD}$ thesis not published. University of Granada. 
Jiménez-Liso, M. R., de Manuel Torres, E., González García, F., \& Salinas López, F. (2000). La utilización del concepto de $\mathrm{pH}$ en la publicidad y surelación con las ideas que manejan los alumnos: aplicaciones en el aula [The use of the concept of $\mathrm{pH}$ in advertising and its relationship with the ideas that students handle: applications in the classroom. Enseñanza de Las Ciencias, 18(3), 451-461. https:/www.raco.cat/index. $\mathrm{php} /$ Ensenanza/article/view/21696.

Jiménez-Liso, M. R., \& de Manuel Torres, E. (2002). La neutralización ácido-base a debate [Acid-base neutralization in discussion]. Enseñanza de Las Ciencias, 20(3), 451-464. https://www.raco.cat/index. $\mathrm{php} /$ Ensenanza/article/view/21837.

Jiménez-Liso, M. R., López-Gay, R., \& Márquez, M. (2010). Química y cocina : del contexto a la construcción de modelos [Chemistry and cooking: from context to building models]. Alambique: Didáctica de Las Ciencias Experimentales, 65(July), 33-44.

Jiménez-Liso, M. R., Martínez-Chico, M., \& Salmerón-Sánchez, E. (2018). Chewing Gum and pH Level of the Mouth : A Model-based Inquiry Sequence to Promote Scientific Practices. World Journal of Chemical Education. https://doi.org/10.12691/wjce-6-X-X.

Jiménez-Liso, M. R., Giménez-Caminero, E., Martínez-Chico, M., Castillo-Hernández, F. J., \& López-Gay, R. (2019). El enfoque de enseñanza por indagación ayuda a diseñar secuencias : ¿Una rama es un ser vivo? [IBSE approach teaching helps design instructional: sequences: a tree branch is a living being?]. In J. Solbes, M. R. Jiménez-Liso, \& T. Pina (Eds.), Propuestas de educación científica basadas en la indagación y modelización en contexto. (pp. 97-119). Tirant lo blanch.

Jiménez-Liso, M. R. (2020). Aprender ciencia escolar implica aprender a buscar pruebas para construir conocimiento (indagación) [Learning school science involves learning to look for evidences to build knowledge (inquiry)]. In D. Couso, M. R. Jimenez-Liso, C. Refojo, \& J. A. Sacristán (Eds.), Enseñando ciencia con ciencia (pp. 60-69). Penguin Random House Grupo Editorial. https://www.fecyt. es/es/publicacion/ensenando-ciencia-con-ciencia.

Justi, R., \& Gilbert, J. K. (1999a). A cause of ahistorical science teaching: use of hybrid models. Science Education, 83(2), 163-177. https://doi.org/10.1002/(SICI)1098-237X(199903)83:2<163::AID-SCE5>3.0.CO;2-I.

Justi, R., \& Gilbert, J. K. (1999b). The history and philosophy of science through models: the case of chemical kinetics. Science \& Education, 8(3), 287-307. https://doi.org/10.1023/A:1008645714002.

Kelly, G. J. (2008). Inquiry, activity and epistemic practice. In R. A. Duschl \& R. E. Grandy (Eds.), Teaching scientific inquiry: recommendations for research and implementation (pp. 99-117). Brill Sense. https://oi. org/10.1163/9789460911453_009.

Kipnis, N. (2011). Errors in science and their treatment in teaching science. Science and Education, 20(7), 655685. https://doi.org/10.1007/s11191-010-9289-0.

Leden, L., Hansson, L., Redfors, A., \& Ideland, M. (2015). Teachers' ways of talking about nature of science and its teaching. Science and Education, 24(9-10), 1141-1172. https://doi.org/10.1007/s11191-015-9782-6.

Lederman, N. G. (2007). Nature of science: past, present, and future. In S. K. Abell \& N. G. Lederman (Eds.), Handbook of research on science education (pp. 831-880). Lawrence Erlbaum Associates.

Lémery, N. (1697). Cours de Chymie (E. Michallet (ed.)).

Lewis, G. N. (1923). Valence and the structure of atoms and molecules (Issue 14). Chemical Catalog Company, Incorporated.

López-Banet, L., Jiménez-Liso, M. R., \& Perales, F. J. (2021). STEAM views from a need: the case of a sensopill gum and $\mathrm{pH}$. Journal for the Study of Education and Development, 44(2), in press.

Lowry, T. M. (1923). The uniqueness of hydrogen. Journal of the Society of Chemical Industry, 42(3), $43-47$.

McClary, L. M., \& Bretz, S. L. (2012). Development and assessment of a diagnostic tool to identify organic chemistry students' alternative conceptions related to acid strength. International Journal of Science Education, 34(15), 2317-2341. https://doi.org/10.1080/09500693.2012.684433.

McComas, W. F. (2006). The nature of science in science education: rationales and strategies. In W. F. McComas (Ed.). Springer Science \& Business Media. https://doi.org/10.1007/978-0-306-47215-2.

Moreno, L., Zuñiga, K., Cofré, H., \& Merino, C. (2018). Efecto (¿o no?) de la inclusión de naturaleza de la ciencia en una secuencia para el aprendizaje y la aceptación de la teoría de la evolución. Revista Lusófona de Educação, 15(3), 3105. https://doi.org/10.25267/Rev_Eureka_ensen_divulg_cienc.2018.v15.i3.3105.

Nakhleh, M. B., \& Krajcik, J. S. (1994). Influence of levels of information as presented by different technologies on students' understanding of acid, base, and ph concepts. Journal of Research in Science Teaching, 31(10), 1077-1096. https://doi.org/10.1002/tea.3660311004.

National Research Council. (2000). Inquiry and the National Science Education Standards. 10.17226/9596.

National Research Council. (2012). A framework for K-12 science education. Practices, crosscutting concepts, and core ideas. The National Academies Press. https://doi.org/10.17226/13165.

Niaz, M. (2009). Progressive transitions in chemistry teachers' understanding of nature of science based on historical controversies. Science and Education, 18(1), 43-65. https://doi.org/10.1007/s11191-0079082-x. 
Nouri, N., McComas, W. F., \& Aponte-Martinez, G. J. (2019). Instructors' rationales and strategies for teaching history of science in preservice settings: illustrations from multiple cases with implications for science teacher education. Science and Education, 28(3-5), 367-389. https://doi.org/10.1007/s11191-019-00055-z.

Nyachwaya, J. M. (2016). General chemistry students' conceptual understanding and language fluency: acidbase neutralization and conductometry. Chemistry Education Research and Practice, 17, 509-522. https://doi.org/10.1039/C6RP00015K.

Oh, P. S., \& Oh, S. J. (2011). What teachers of science need to know about models: an overview. International Journal of Science Education, 33(8), 1109-1130. https://doi.org/10.1080/09500693.2010.502191.

Osborne, J. (2014). Teaching scientific practices: meeting the challenge of change. Journal of Science Teacher Education, 25(2), 177-196. https://doi.org/10.1007/s10972-014-9384-1.

Ottonello, G., \& Moretti, R. (2004). Lux-Flood basicity of binary silicate melts. Journal of Physics and Chemistry of Solids, 65(8-9), 1609-1614. https://doi.org/10.1016/j.jpcs.2004.01.012.

Özmen, H., DemIrcIoĞlu, G., \& Coll, R. K. (2009). A comparative study of the effects of a concept mapping enhanced laboratory experience on Turkish high school students' understanding of acid-base chemistry. International Journal of Science and Mathematics Education, 7(1), 1-24. https://oi.org/10.1007/s10763-007-9087-6.

Paik, S. H. (2015). Understanding the relationship among Arrhenius, Bronsted-Lowry, and Lewis theories. Journal of Chemical Education, 92(9), 1484-1489. https://doi.org/10.1021/ed500891w.

Pareja Roblin, N., Schunn, C., \& McKenney, S. (2018). What are critical features of science curriculum materials that impact student and teacher outcomes? Science Education, 102(2), 260-282. https://doi.org/10.1002/sce.21328.

Pearson, R. G. (1963). Hard and soft acids and bases. Journal of the American Chemical Society, 85(22), 35333539. https://doi.org/10.1021/ja00905a001.

Pedaste, M., Mäeots, M., Siiman, L. A., de Jong, T., van Riesen, S. A. N., Kamp, E. T., Manoli, C. C., Zacharia, Z. C., \& Tsourlidaki, E. (2015). Phases of inquiry-based learning: definitions and the inquiry cycle. Educational Research Review, 14, 47-61. https://doi.org/10.1016/j.edurev.2015.02.003.

Quílez, J. (2019). A categorisation of the terminological sources of student difficulties when learning chemistry. Studies in Science Education, 00(00), 1-47. https://doi.org/10.1080/03057267.2019.1694792.

Rau, G. (2009). An activity to help students learn about observation, interpretation, and argumentation. The Science Teacher, 76(8), 30-35 https://search.proquest.com/openview/d17fb9b36f453372be586adc1496650 $\mathrm{a} / 1$ ?pq-origsite $=$ gscholar $\& \mathrm{cbl}=40590 \& \mathrm{cas}$ a token $=$ uoJUIA-q53cAAAAA: hqasIJWD5 BmriLScKiuaHXvbKkDumwnjVpSRjKWqAKUbiRw1EGLWN7po todPcPWWI5fdzboXbNL.

Rollnick, M. (2019). Introduction. In S. Erduran \& E. Kaya (Eds.), Transforming teacher education through the epistemic core of chemistry (pp. XIII-XV). Springer. https://doi.org/10.1007/978-3-030-15326-7.

Ross, B., \& Munby, H. (1991). Concept mapping and misconceptions: a study of high-school students' understandings of acids and bases. International Journal of Science Education, 13(1), 11-23. https:/doi. org/10.1080/0950069910130102.

Sadler, T. D., \& Zeidler, D. L. (2009). Scientific literacy, PISA, and socioscientific discourse: assessment for progressive aims of science education. Journal of Research in Science Teaching, 46(8), 909-921. https://doi. org/10.1002/tea.20327.

Scerri, E. R. (2019). Five ideas in chemical education that must die. Foundations of Chemistry, 21(1), 61-69. https://doi.org/10.1007/s10698-018-09327-y.

Schmidt, H.-J. (1991). A label as a hidden persuader: chemists' neutralisazion concept. International Journal of Science Education, 13(4), 459-471. https://doi.org/10.1080/0950069910130409.

Schneider, R. M., \& Plasman, K. (2011). Science teacher learning progressions: a review of science teachers' pedagogical content knowledge development. Review of Educational Research, 81(4), 530-565.

Schwarz, C. V., Reiser, B. J., Davis, E. A., Kenyon, L., Acher, A., Fortus, D., Shwartz, Y., Hug, B., \& Krajcik, J. (2009). Developing a learning progression for scientific modeling: making scientific modeling accessible and meaningful for learners. Journal of Research in Science Teaching, 46(6), 632-654. https://doi. org/10.1002/tea.20311.

Shen, J., \& Confrey, J. (2007). From conceptual change to transformative modeling: a case study of an elementary teacher in learning astronomy. Science Education, 91(6), 948-966. https://doi.org/10.1002/sce.

Sheppard, K. (2006). High school students' understanding of titrations and related acid-base phenomena. Chemistry Education Research and Practice, 7(1), 32-45. https://doi.org/10.1039/b5rp90014j.

Stavridou, H., \& Solomonidou, C. (1998). Conceptual reorganization and the construction of the chemical reaction concept during secondary education. International Journal of Science Education, 20(2), 205-221. https://doi.org/10.1080/0950069980200206.

Stavy, R. (1990). Pupils' problems in understanding conservation of matter. International Journal of Science Education, 12(5), 501-512. https://doi.org/10.1080/0950069900120504.

Stefani, C., \& Tsaparlis, G. (2009). Students' levels of explanations, models, and misconceptions in basic quantum chemistry: a phenomenographic study. Journal of Research in Science Teaching, 46(5), 520-536. https://doi.org/10.1002/tea.20279. 
Taber, K. S. (2001). Building the structural concepts of chemistry: some considerations from educational research. Chemistry Education Research and Practice, 2(2), 123. https://doi.org/10.1039/b1rp90014e.

Tarhan, L., \& Acar Sesen, B. (2012). Jigsaw cooperative learning: acid-base theories. Chemistry Education Research and Practice, 13(3), 307-313. https://doi.org/10.1039/c2rp90004a.

Tasquier, G., Levrini, O., \& Dillon, J. (2016). Exploring students' epistemological knowledge of models and modelling in science: results from a teaching/learning experience on climate change. International Journal of Science Education, 38(4), 539-563. https://doi.org/10.1080/09500693.2016.1148828.

Taton, R. (1957). La science antique et médiévale. Presses Universitaires de France.

Taton, R. (1959). Histoire générale des sciences, t. II: La science moderne. Presses Universitaires de France.

Taton, R. (1964). Histoire générale des sciences. Presses Universitaires de France.

Taton, R., \& Goupil, M. (1961). Histoire des sciences. In T. III-La science contemporaine (Vol. 1).

Usanowitsch, M. (1939). Theory of acids and bases. J. Allg. Chem.(USSR), 9, 182-198.

Uskola Ibarluzea, A. (2016). ¿Los productos homeopáticos pueden ser considerados medicamentos? Creencias de maestras/os en formación [Homeopathic products can be considered medicine? Beliefs of elementary preservice teachers]. Revista Eureka Sobre Enseñanza y Divulgación de Las Ciencias, 13(3), 574-587. https://doi.org/10.25267/Rev Eureka ensen divulg cienc.2016.v13.i3.05.

Wandersee, J. H. (1986). Can the history of science help science educators anticipate students' misconceptions? Journal of Research in Science Teaching, 23(7), 581-597. https://doi.org/10.1002/tea.3660230703.

Wynne, B. (1989). Sheepfarming after Chernobyl a case study in communicating scientific information. Environment: Science and Policy for Sustainable Development, 31(2), 10-39. https://doi.org/10.1080 /00139157.1989.9928930.

Yalcin, F. (2011). Investigation of the change of science teacher candidates' misconceptions of acids-bases with respect to grade level. Journal of Turkish Science Education, 8(3), 161-172 http://tused.org/index. $\mathrm{php} /$ tused/article/view/377.

Zoller, U. (1990). Students' misunderstandings and misconceptions in college freshman chemistry (general and organic). Journal of Research in Science Teaching, 27(10), 1053-1065. https://doi.org/10.1002 /tea.3660271011.

Publisher's Note Springer Nature remains neutral with regard to jurisdictional claims in published maps and institutional affiliations. 